rumson

glyndŵn

Glyndŵr University

Glyndŵr University Research Online

Theology

Theology

$1-1-2006$

\title{
A nine country survey of youth in Europe: selected findings and issues
}

William K. Kay

GlyndwrUniversity, w.kay@glyndwr.ac.uk

H G. Ziebert

Follow this and additional works at: http:// epubs.glyndwr.ac.uk/theo

Part of the Religious Thought, Theology and Philosophy of Religion Commons

This is an electronic version of an article published in Kay, W. K., \& Ziebertz, H. G. (2006)'A nine country survey of youth in Europe: selected findings and issues'.British Journal of Religious

Education, 28(2), 119-129. British Journal of Religious Education is available online at http://www.informaworld.com

\section{Recommended Citation}

Kay, W. K., \& Ziebertz, H. G. (2006)'A nine country survey of youth in Europe: selected findings and issues'.British Journal of Religious Education, 28(2), 119-129

This Article is brought to you for free and open access by the Theology at Glyndŵr University Research Online. It has been accepted for inclusion in Theology by an authorized administrator of Glyndŵr University Research Online. For more information, please contact d.jepson@glyndwr.ac.uk. 


\title{
A nine country survey of youth in Europe: selected findings and issues
}

Revd Dr. William K Kay

Professor of Theology at Glyndwr University

and

Prof.Dr.Hans-Georg Ziebertz

Professor of Practical Theology

University of Würzburg

\begin{abstract}
A nine country survey of the life orientations, values and institutional trust of 8948 young people at the upper end of the secondary school age range was set up at the University of Würzburg in the year 2000. Key findings demonstrate that these young people value personal autonomy and are orientated to success in their professional lives and that they especially trust human rights and environmental groups. Religion is associated positively with humanitarianism and in some countries negatively with modernity. These findings provide an indication of the typical life stances of future opinion-formers and illustrate methodological issues thrown up by international research.
\end{abstract}




\section{Introduction}

This paper introduces a multi-national project on religion and values.

The development of religious education in Britain since 1945 has a followed a trajectory that has been driven by a variety of factors (Kay, 1981; Copley, 1997). Empirical research into the cognitive abilities of young people and their attitudes have played their part (Goldman, 1964; Murphy 1977, 1978; Francis 1987, 1989; Hyde 1990; Kay and Smith, 2001) and these have been contextualised within educational changes to the configuration of schooling, especially through the introduction of comprehensive of schools in the late 1960s. But more recent less empirically-driven changes have also impacted the curriculum, especially through the introduction of the national curriculum as a result of the 1988 Education Reform Act. Similar changes to religious education have been followed in other European countries (Schreiner, 2000; Bakker and Griffioen, 2001; Heimbrock, Scheilke and Schreiner, 2001) and, where issues arising from the co-existence of many religious groups within a modern democratic society have impinged in one way or another on the classroom, the various educational systems within the different countries of Europe have been faced with essentially the same pedagogic problems.

While the aspirations and rights of religious groups have been implicit in the various national debates, so also have been the attitudes and beliefs of young people themselves (Kay, 1997; Sterkens, 2001; Ziebertz, 2001). Yet there have been few studies that have attempted to the deal with religion in the life of young people against an understanding of their values, attitudes, religious socialisation and political consciousness. In other words, in no other multi-national study of which we are aware has religion been conceptualised within the totality of young people's lives including a consideration of the social forces that impinge upon them and the social perceptions that shape them.

More recently citizenship has appeared on the curriculum in England and Wales. It is a subject that lends itself to cooperation with RE (Jackson, 2003) though in its most extreme forms it is a subject that refuses to confine itself to the classroom and spreads its concerns to the entire ethos of the educational system. ${ }^{1}$ Advocates of citizenship (Kerr, 1999a, 1999b; Kerr et al, 2001; cf also Lawton, Cairns and Gardner, 2000) have also tended to argue for a holistic approach that inevitably includes cross disciplinary elements as well as rational and social perspectives. Yet, citizenship in the UK must necessarily relate to citizenship in Europe since the citizens of member countries are also citizens of the larger geo-political reality. Indeed the only way to become a citizen of Europe is to become a citizen of a state that is itself a member of the EU. Citizenship education (CE) in the UK therefore includes European dimensions of a variety of kinds.

For these reasons, a research project coordinated by Hans-Georg Ziebertz of the University of Würzburg and later partially funded by the German Science Council (DFG) was set up in 2000 and involved nine countries with Turkey, a tenth, a participant in the second part of the project. The nine countries are Germany, the United Kingdom, Poland, the Netherlands, Sweden, Finland, the Republic of Ireland, Croatia and Israel ${ }^{2}$. At an early stage the decision was taken to utilise quantitative methods. Within Germany the Shell youth surveys have

\footnotetext{
${ }^{1}$ http://eppi.ioe.ac.uk/EPPIWeb/home.aspx?page=/reel/eppi-ed_conference.htm

${ }^{2}$ Israel, of course, is not in Europe but it offers a very European approach to religious schooling (different types of religious schools) and pedagogics. From another angle, it offers an interesting contrast with the specifically European countries.
} 
been run since the 1950s and these have charted the gradual evolution of young people's beliefs, attitudes and values over time. Similarly, the British Social Attitudes (BSA) surveys have been regularly monitoring changes in attitudes among the whole age range of the population since 1985. ${ }^{3}$ Before this the European Values Survey (EVS) (e.g. Barker, Halman and Vloet, 1993) using interviews and a whole population age range carried out a series of studies from 1978 onwards to see whether Europeans share common values and if Christian values permeate European life and culture. Prior to this, the International Project for the Evaluation of Educational Achievement (IEA) started in 1959 and proceeded by way of a study of 12 countries. By 1966, it had grown to 22 countries. In each country the same educational tasks, carried in a questionnaire, were placed before pupils in a classroom setting (Peaker, 1967; Comber and Keeves, 1973; Coleman 1975). There is therefore a research tradition upon which to build. Consequently participants were invited to contribute to the concepts or blocks of questions in a questionnaire and, after this process had been completed, items were pilot tested. The questionnaire addresses relatively large samples of pupils in each of participating countries and does not depend upon a much smaller number of interviews, which would have been the other option. Moreover the translation of large amounts of interview material into a common language would be problematic whereas a database, even if it is related to questionnaires that were originally distributed in different languages, can be constructed to handle identical variables and these variables can be measured with precision allowing the conceptual models to which they relate to be tested. Because all this depends on mathematical or statistical manipulation, it is largely independent of culture or language and so more easily open to international comparison and generalisation; a correlation coefficient is calculated the same way all over the world.

In each of the countries the same questionnaire, suitably translated, was distributed to pupils of around the age of 17 and, because of the length and intricacy of some of the questions, it was prepared with more able pupils in mind. Germany, for instance, has a selective system of education in which approx only the top 30\% of academically able pupils attend the gymnasium and it was for pupils in this category that the questionnaire was largely designed. The rationale behind this decision is that the questionnaire is aimed at those who, in each country, would be expected to become leaders in politics and commerce in their own generational cohort. These young people are the opinion-makers of the future and the ones who are the most sophisticated in their judgements and most knowledgeable in their opinions. Full details are given in Ziebertz and Kay (2005).

\section{Concepts and variables}

The project was from the first conceived in a way that would allow the individual young person to be located within a socio-demographic context. For this reason, the variables used within the questionnaire were related to concepts at the micro-level: these were concerned with personal life-planning like those related to pessimism, one's need for security, orientation towards the present, personality dimensions, and so on. In addition there were items relating to personal values like the desire to be modern, attractive, authentic, to be orientated towards the family or work, to be autonomous or to be humane. Then there were variables at the meso-level which included trust in organisations relating to parliament, interest groups (trade unions, churches), the mass media, social regulation (the courts and the

\footnotetext{
${ }^{3}$ There are 31 countries in the International Social Survey Programme (ISSP) and 'each undertakes to field the same module of questions each year among a nationwide, probability-based sample of adults' (Jowell, Curtice, Park, Brook, Thomson and Bryson, 2000: xiv). The project has produced an annual report.
} 
military) and to issue-related groups (like Amnesty International and Greenpeace) and finally variables were grouped at the macro-level and dealt with the arena of public life, political parties and willingness to undertake political or parliamentary action.

This division of variables was predicated on the assumption that institutions mediate the larger political reality to individuals but that they do so in a way that is dependent upon the trust individuals place in them. There is thus interaction here between the individual's perceptions about the police, the media, the trade unions, and so on, and the individual's own value system. So we take the view that organisations are able much more directly than the larger political processes to relate meaningfully to the way an individual feels or, to put this the other way, some individuals are more disposed to trust, say, the churches, the police or the trade unions than others. Nevertheless the larger perspectives relating to national government and bureaucracy in Europe or to the impact of Europe are genuine and worth measuring. The analysis of the data begins at the micro or individual level, assesses the meso or institutional level and concludes with the macro or political and European level.

Each cohort of young people in each country was analysed separately. These young people were born in the late 1980s and have had very different life experiences. For some, their lives began under communism (Poland) and for others the aftermath of war (Croatia) is a reality. For others, the prosperity of the childhood is now being threatened by relatively high levels of unemployment as these young people move towards the job market (Germany) and for others political uncertainty arising from debate about the multicultural nature of their society is evident (The Netherlands). The analysis for each country was carried out by a scholar native to that country but all of them took the view that their findings should be interpreted in the light of the country's modern history. So, for instance, if their young people show a desire for security or a sense of impending social chaos, these can be connected with the political and economic events likely to engender such concerns. While we recognise that there are interpretive assumptions at work here, we consciously follow in the BSA tradition established by Renwick and Toka (2000: 149-168) who found that there was among ex-Communist countries a greater unwillingness to accept left-wing views than there was among those who had lived all their lives within a liberal democracy. In other words, those who had tasted the bitter medicine of communism were in no mood to be given further doses of it whereas those who had been opened to the ravages of the free market were more inclined to accept collectivist ideals.

In relation to religion two other analytic measures were introduced. The first concerned the contrast or connection between the religious beliefs and practices of the parents and the religious beliefs and practices of the young person. A fourfold classification was constructed. There were young people who came from a practising religious home who were themselves practicing believers; there were young people who came from a practising religious home who were not believers; and there were young people who came from secular homes who were believers; there were young people who came from secular homes who were themselves secular. In this way it was possible to see whether there was a drift from religious homes to secularity or from secular homes to religiousness and to assess the shift country by country. Not unexpectedly the shift was largely in the direction of secularity although there was some movement in the opposite direction. The classificatory system was religiously neutral and worked equally well with Christian, Jewish, Muslim, Sikh, Hindu or any other young people.

The second was more directly concerned with religious education. Here the presumption was that pupils might adopt a mono-religious approach to RE (where only one religion is thought 
to be true), a multi-religious RE (where all religions may be equally true) and an interreligious RE (where each religion is seen in the light of others) (Ziebertz, 2005). For each of these approaches scales were constructed and tested. In addition these scales were set against the aims of RE that pupils might endorse. Altogether 11 aims were presented to pupils for response on a five point scale.

Clearly, a large variety of hypotheses are testable. In relation to religion we might ask whether recently secularised young people are more likely to adopt a multi-religious or an inter-religious approach. We might ask whether the Christian groups are more or less likely to adopt multi-religious orientations than non-Christian groups. Equally we could explore the connection between the religiousness of the home and trust in various kinds of institutions in the different countries. We could look at the relationship between the religiousness of the home and personal values of autonomy or humanity. We could compare religious young people with secular young people in relation to their stance towards time. Are religious young people more likely to value the past more than secular young people? In other words we can begin to attempt to disentangle aspects of the micro-world of young people in relation to their perception of the kind of religious teaching they receive in schools and their preferences for one kind teaching or another.

The richness of the data as well as the fact that it is a collected from nine (or 10) countries is too great to be presented within the parameters of a single paper or even a single book. For this reason the project has been designed to issue its findings in three stages corresponding with three volumes. The first will deal with life orientations, values and European questions. The second is concerned to discuss religion in the lives of young people. The third step is focused on the relation between perspectives on life and religious attitudes.

\section{Participants and samples}

The sample is made up of pupils from large countries (Germany) and small countries (Croatia). All of them apart from Israel are within the main body of Europe and all of them, except Croatia, are actually within the European Union, and Croatia aspires to be within the Union. The countries cover the west of Europe (the Republic of Ireland) and eastern Europe (Poland) as well as the northern (Finland, Sweden) and the central parts of Europe (the Netherlands). Sweden and Finland are predominantly Protestant, Germany is mixed between Protestant and Catholic in roughly equal numbers, Poland and Croatia are largely Roman Catholic and the UK and the Netherlands have strong Protestant representation despite being largely secularised. Germany, the UK and the Netherlands have significant immigrant populations. Poland and Croatia were for many years behind the Iron Curtain. It is therefore reasonable to argue that the countries participating in the study represent many of the different aspects of today's Europe. ${ }^{4}$ They are not, however, intended to represent the European Union which is, by most definitions, covers a different surface area from that which comprises what is historically called Europe. It is true, though, that France, Italy, Spain and Greece were invited to participate in the current study and were not included because of lack of funding from the EU.

\footnotetext{
${ }^{4}$ The Turkish sample is still being collected which is why data from it has not been used in the first part of the overall project. No further reference will be made to Turkey in this paper but mention of it is included here since future papers are planned, some of which will use Turkish data.
} 
The names of the project leaders in the individual countries and the size of their samples are given in table 1. The total number of pupils who participated is 8948 and there are a roughly equal number of males and females.

Full details of the composition of the sample will be given in Youth in Europe (volume 1, eds Ziebertz and Kay) which is due to be published during 2005. To avoid disproportionality in mapping onto the actual sizes of national populations, the analysis has been carried out on a country by country basis rather than on the database as a whole.

\section{Selected findings}

The questionnaire provided a list of eight values at the micro-level that had been derived from the Shell youth studies. These included autonomy, humanity, self-management, attractiveness, modernity, authenticity, family orientation, and professional orientation. Each value was measured by a four item scale. There was remarkable agreement about the top three values accepted by young people in each of the nine countries. The value of autonomy (with items referring to: leading one's own life, of thinking and acting independently, of holding onto one's own personal opinion and of having the courage to say 'no') comes top in five of the countries (Germany, the UK, the Netherlands, Sweden, Finland) and in three other countries (Ireland, Croatia and Israel), it comes within the top three. Only in Poland is autonomy out of the top group. Across the vast majority of Europe, and in Israel, there is clear desire for autonomy which, in this context, means almost the same as individuality and of 'being true to oneself'. At the same time and at first sight paradoxically, the value of humanity (with items referring to: being ready to help others, share with others and doing something for society, accepting every person the way he or she is) is also within the top three in all nine countries. The third value that is within this trio is a professional orientation (with items referring to: wanting a good education, looking for a solid job that allows independence, looking for a meaningful job, looking for a stable job) is also common to all the countries apart from The Netherlands.

The combination of these three values builds up a picture of a typical more academically inclined young European as someone who is looking for independence through professional success while, at the same, time wanting to maintain humanitarian values. In Poland which is a partial exception to the rule, young people replace autonomy with an orientation towards the family.

At meso-level there are again huge similarities. The questionnaire gave a list of 14 agencies for rating on a five point scale: employer organisations, citizen's groups, government, parliament, the military, television, courts, trades unions, churches, human rights groups, political parties, the police, environmental protection groups, and newspapers. In every country apart from Finland human rights groups come within the top three institutions and in Germany, the UK, the Netherlands, the Republic of Ireland and Croatia they attract the highest degree of trust. These single-issue groups campaigning for the rights of ordinary people are recognised and valued more than governments, the media, the trade unions and employers' organisations. And it is worth bearing in mind that Amnesty International campaigns against the persecution of individuals provided that these individuals have never used or advocated the use of violence. So the appeal of human rights groups is consonant with non-violent protest against all forms of persecution. In addition and within Germany, the UK, the Netherlands, Sweden, Finland and Israel either the police or the courts also come 
within the top three. In Poland and Croatia the church replaces these agencies. In Israel the military is the most trusted of institutions. In Germany, the UK, Poland, the Republic of Ireland and Croatia environmental groups are also among the top three. And, in almost every country, political parties and the media were the least trusted.

The surprise in these figures is to be found in the trust placed by young people in the police and in the courts. ${ }^{5}$ Admittedly, these bright young people are the ones least likely to be involved in law-breaking. They expect to succeed within today's ordered and largely meritocratic liberal democracies without recourse to crime. Such success (indicated by the professional orientation) is anticipated despite alienation from politics whether in the form of trade unionism, political parties or employers' organisations. From findings elsewhere in the questionnaire it is evident that young people actively dislike their parliamentary representatives and blame them for mishandling human and other resources to the extent that these young people feel that they will have to pay dearly for the mistakes of their current political masters. Citizenship education will consequently have the task of moderating young people's generalised critical views of their political classes. This, after all, is education in citizenship, not education in revolution.

The role of religion in each of the countries, regardless of which religion is in view, is consistent. If someone designates themselves as 'religious' he or she likely to have a greater respect for the past than those who do not designate themselves in this way. So religion functions to raise the value of the past, even the personal past (as in the item, 'I enjoy thinking about my past') and enhance its utility and, presumably, to provide a force for stability within the life of young people. At the same time religion is also significantly correlated with the value of humanity in each of the countries sampled here. This implies that religion carries humanitarian values that are imbibed by the young people who consider themselves to be religious. In the lives of young people religion also can facilitate the ability to critique the present with its fashions and trends (there are negative correlations between religious self-ascription and modernity in Germany, The Netherlands and Croatia). In this respect when young people 'learn from' religion during religious education, they may be expected to enlarge their imaginative capacities by being enabled to envisage alternative futures and states of being.

\section{Reflection}

Because of the extent of the material covered by the questionnaire and the cultural and historical differences between the participating countries, we conclude with methodological and substantive reflections. Methodologically, the analysis of the questionnaire data needed to be cautious about the fact that the samples in the different countries were constituted differently. For instance, the collection of pupil data within a selective system of education must be different from the collection of data within a comprehensive system of education. Consequently the analysis has allowed each country to examine variables in relation to each other. It makes sense for each country to see the rank order of institutions in terms of their trustworthiness. One is not comparing the trustworthiness of German police with Swedish trade unions but comparing the Swedish institutions with each other in the eyes of the

\footnotetext{
${ }^{5}$ Francis and Kay (1995) in a sample of 13,000 young people found that only 59\% of year 9 pupils in the UK agreed that 'the police do a good job' (table 8.3). Francis (2001), in a sample of more than 30,000 pupils aged between 13 and 15 in the UK, found only 54\% agreed that 'the police do a good job' (table 2.13). Quoting Farrington (1990), Francis notes that peak rates of offending behaviour occur between 15 and 19 years.
} 
Swedish sample and the German institutions with each other in the eyes of the German sample.

Nevertheless, these data will allow for quite careful comparisons between males and females within the different countries. There are undoubtedly variations of expectation within European countries about the role of women. The former eastern countries, for instance, have moved much more slowly in relation to the liberation of women than countries like The Netherlands or the UK. Having made an examination of the differences between males and females within countries we suspect that, despite the country by country approach we have adopted, there will then be justification for a similar examination between countries. Thus methodologically, we wish to draw attention to the possibilities for comparisons of different types: essentially we are offering a paradigm that is distinct from the EVS and IEA surveys mentioned earlier, though one that allows both intra- and inter-country comparisons.

Substantively, the survey here has conceived of religion as operating within the complex psychological and social worlds of young people. This appears to be an ultimately more promising design than that which simply picks out certain beliefs in samples in different countries and sees what the frequencies are. There are surveys (e.g. Gallup and Lindsay, 1999: 127) that have asked questions about belief in God across a range of different countries and over time and, while we would not wish to diminish the importance of these, we feel that the present approach allows a better analysis of the reasons why certain beliefs should be high or low in particular countries. In short, the richer data allow for more complete causal models to be designed and tested.

There is also the possibility in this more holistic approach of seeing how religion operates in relation to politics, and especially to citizenship. There is an implicit notion here that religion may be seen both in terms of its functions within the lives of individuals and also as a background variable like age or sex. Certainly the relationship between religion and the assessment of politicians and the democratic process allows interesting profiles to be drawn of typical individuals. We have, for instance, drawn profiles of the typical pro-European and the typical anti-European. The pro-European, often female, is likely to embrace green values and to trust most major social institutions (including religious ones) while the anti-European, often male, takes a much less sanguine view of the political classes and of major social institutions. Indeed in these samples anti-Europeans tend to less professionally orientated and there is an unfortunate tendency in the case of some pupils for these attitudes to be contaminated by a willingness to use political violence. Obviously, the connection between religion and politics may have implications for the teaching of RE within school systems across Europe.

Our findings accord with those of Barker, Halman and Vloet (1993) in respect of the importance of autonomy for these young people, but we differ from the EVS studies in finding that autonomy is not simply an expression of post-materialist values but rather is being coupled with professional competence. In our view these young people believe autonomy is going to be achieved through their professional competence, and this is especially so in the minds of young women. Religious belief moderates professional ambition and is linked in most countries with a general humanitarianism. We intended to draw out the implications of these findings after more thorough analysis at a later stage in this project. 
Finally the contextualisation of aspects of these data against the major economic and political events within the different countries appears to provide a flexible approach to interpretation and meaning. We find, for instance, that Irish young people are more positive than German young people and can with some reason attribute this to the rapid economic prosperity that Ireland has achieved and the sudden stagnation within the economy of the newly unified Germany. Equally we can plausibly suggest that the marketisation of Britain under Mrs Thatcher produced a higher valuation of educational qualifications and see this, and the success of women within the educational system, as important lines of interpretation. 
Table 1: countries, participants and samples

\begin{tabular}{llc}
\hline Country & Project Leader & No. of Respondents \\
\hline Germany & Hans-Georg Ziebertz, Würzburg & 1925 \\
Great Britain & William K Kay, Bangor & 1083 \\
Poland & Wit Pasierbek, Krakov & 798 \\
The Netherlands & Leo van der Tuin, Tilburg & 816 \\
Sweden & Per Petterson, Uppsala & 757 \\
Finland & Eila Helander, Helsinki & 588 \\
Ireland & Christopher Alan Lewis, Londonderry & 1065 \\
Croatia & Gordan Cripic, Zagreb & 1064 \\
Israel & Zehavit Gross, Ramat Gan & 852 \\
& & \\
TOTAL & & 8948 \\
\hline
\end{tabular}

International coordination: Hans-Georg Ziebertz, Würzburg 


\section{Bibliography}

Bakker, K. and Griffioen, K. (eds.) (2001), Religious Dimension in Intercultural Education: theory and practice, Oistwerwijk: Dutch University Press.

Barker, D., Halman, L. and Vloet, A. (1993), The European Values Study 1981-1990, London/The Netherlands, European Values Group

Coleman, J. S. (1975), Methods and results of IEA studies of effects of school on learning, Review of Educational Research, 45, 335-386.

Comber, L. C. and Keeves, J. P. (1973), Science education in nineteen countries: international studies in evaluation, vol 1, Stockholm: Almqvist Wiksell.

Copley, T. (1997), Teaching Religion: fifty years of religious education in England and Wales, Exeter, University of Exeter Press.

Farrington, D.P. (1990), Age, period, cohort and offending, in D.M. Goltfredson and R.V. Clarke (eds), Policy and Theory in Criminal Justice: contributions in honour of Leslie T Wilkins, pp. 51-75, Aldershot, Avebury.

Francis, L.J. (1987), The decline in attitudes towards religion among 8-15 year olds, Educational Studies, 13, 125-134.

Francis, L.J. (1989), Monitoring changing attitudes towards Christianity among secondary school pupils between 1974 and 1986, British Journal of Educational Psychology, 59, 86-91.

Francis, L.J. (2001), The Values Debate, London, Woburn Press.

Francis, L.J. and Kay, W.K. (1995), Teenage Religion and Values, Leominster, Gracewing.

Gallup, G. and Lindsay, D. M. (1999), Surveying the Religious Landscape, Harrisburg, PA: Morehouse Publishing

Goldman, R. (1964), Religious thinking from childhood to adolescence London: Routledge and Kegan Paul.

Heimbrock, H-G, Scheilke, C.Th and Schreiner P. (2001) (eds) Towards Religious Competence: diversity as a challenge for education in Europe, Berlin, LIT Verlag Munster.

Hyde, K. E. (1990), Religion in Childhood and Adolescence. Birmingham, Al: Religious Education Press.

Jackson, R (ed) (2003), International Perspectives on Citizenship, Education and Religious Diversity, London, RoutledgeFalmer.

Jowell, R., Curtice, J., Park, A., Brook, L., Thomson K. and Bryson C. (eds.) (2000), British and European Social Attitudes: the 15th report, Aldershot: Ashgate.

Lawton D., Cairns J. and Gardner R. (2000), Education for Citizenship, London, Continuum.

Kay, W K (1981), Factors Bearing on Changes in Religious Education in Britain since 1944, Journal of Christian Education, papers 72, 20-30.

Kay, W. K. (1997), Belief in God in Great Britain 1945-1996: moving the scenery behind classroom RE, British Journal of Religious Education 20, 1, 28-41.

Kay, W. K. and Smith, D. L. (2001), Quantitative work from the inside: numbers, problems and policy, British Journal of Religious Education, 23, 3, 177-187.

Kerr D. (1999a) Re-examining Citizenship Education: The Case of England, Slough, NFER.

Kerr D. (1999b) Citizenship Education: An International Comparison, London, QCA/NFER.

Kerr, D., Lines, A., Blenkinsop, S. and Schagen, I. (2001), Citizenship and Education at Age 14: a summary of the international findings and preliminary results for England. Slough: NFER.

Murphy, R.J.L. (1977), Does children's understanding of parables develop in stages? British Journal of Religious Education, 16, 168-172.

Murphy, R.J.L. (1978), A new approach to the study of the development of religious thinking 
in children, Educational Studies, 4, 19-22.

Peaker, G. F. (1967), Sampling, in T. Husen (ed), International Study of Achievement in Mathematics (vol 1), Stockholm: Almqvist Wiksell.

Renwick, A and Tabor, G. (2000), East meets west, in R. Jowell, J. Curtice, A. Park, L Brook, K.Thomson and C. Bryson (eds.), British and European Social Attitudes: the 15th report, Aldershot, Ashgate.

Schreiner, P. (ed), (2000), Religious Education in Europe, Münster, ICCS and ComeniusInstitut.

Sterkens, C. (2001), Interreligious Learning: the problem of Interreligious Dialogue in Primary Education, Leiden: Brill.

Ziebertz, H-G (2001), Change in religion - problem and challenge, in H-G Ziebertz (ed), Religious Individualization and Christian Religious Semantics, Hamburg: Lit Verlag.

Ziebertz, H-G (2005), Models of inter-religious learning: an empirical study in Germany, in L. J. Francis, M. Robbins and J. Astley (eds), Religion, Education and Adolescence: international empirical perspectives, Cardiff: University of Wales Press, p204-221.

Ziebertz, H.-G. and Kay, W. K. (Eds) (2005), Youth in Europe I: An international empirical Study about Life Perspectives, Münster/Hamburg/London: LIT Verlag. 